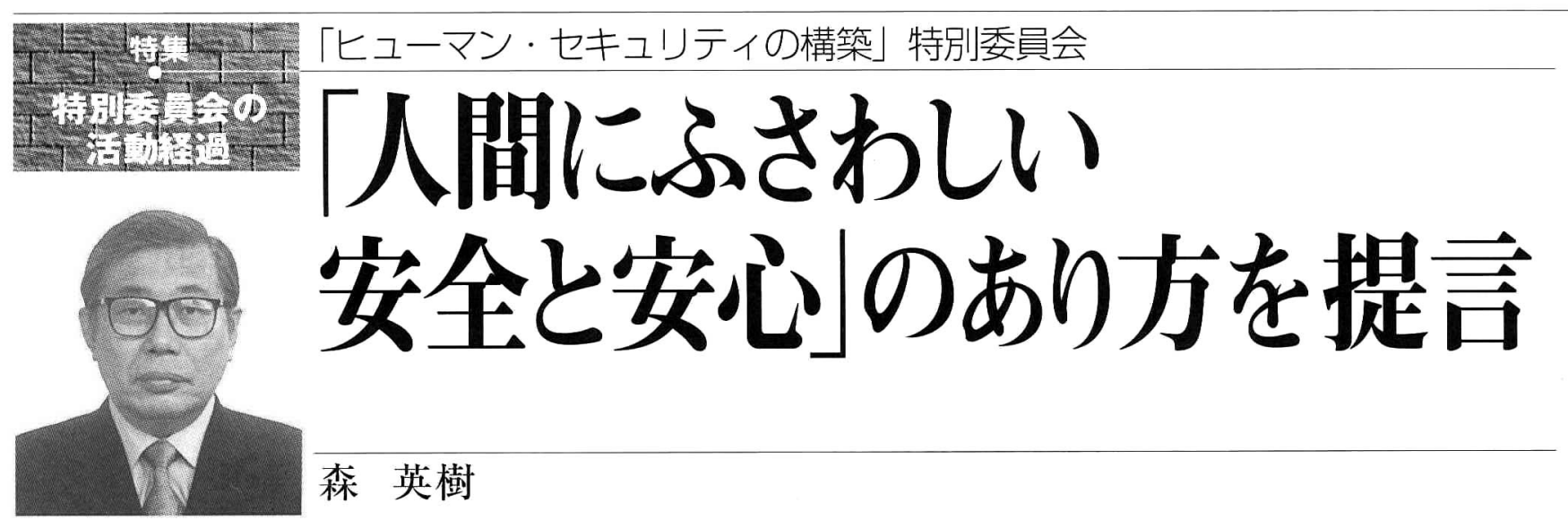

\section{national securityから}

\section{human securityへ}

国際社会の場面で使用されてきたsecurityという 概念は、これまで「安全保障」と訳され、もっぱら 国家単位での、軍事を軸とした国家間に打ける安全 保障 (national security) として長らく理解されてき た。この概念の下では、国家内のsecurity（たとえ ば福祉国家の核心であるsocial security=社会保 障）は、論理的にも現実的にも問われることがない。

しかし、すでに冷戦下においても、1980年代前 半に、パルメ委員会が「共同の安全保障 (common security)」という概念を提唱して「国家安全保障」 に対するオールタナティヴを示したように、国家中 心・軍事中心の安全保障観の転換が意識されるよう になった。冷戦構造崩壊後は、人類的生存が地球的 規模で脅威にさらされている諸問題をもsecurityの 課題としてとらえ始めている（たとえばenvironmental security, world security)。

そのような動向の中で、国連専門機関のひとつで ある国連開発計画 (UNDP) が1994年に発表した 「人間開発計画1994」が、「human security」という 考え方を提唱し、その後世界的にこの言葉が普及す るようになった。この「人間開発計画1994」では、 「いまこそnational securityという狭義の概念から、 human securityという包括的な概念に移行すべき 時である」として、「securityに関する考え方を二つ の基本的方法で切り替えること」、すなわち「領土 保全のsecurityから人間を重視したsecurityへ」、 扰び「軍備によるsecurityからsustainable human developmentへ」という方向を説いている。 もとよりこの考え方は、国家安全保障を排余はし ていない。しかし安全保障観のパラダイム転換を提 唱していることは確かであうう。human security には「人間の安全保障」という訳語があてられるが、 「安全保障」という日本語には、どうしても国家中 心・軍事中心の印象があるので、そのまま「ヒュー マン・セキュリティ」とするケースが少なくない。

ともあれ、かくして、human securityというキ 一ワードは、日本政府も含む各方面から注目・多用 されるようになり、世界的にも、「安全保障」を国 家から個人のレベルで捉え返し、人間が人間である ための権利を正当に行使できるようなシステムをい かにしたら構築することができるかという観点や、 それを現実に可能にするさまざまな担い手を念頭に 置いたガバナンスのあり方を追求する観点として、 内外で重視されるようになった。ただし、他方でこ の概念は、その具体的内容が一義的に明確ではない ため、さまざまな含意で多用され、その意義が搪散 しているきらいがないではない。 


\section{ヒューマン・セキュリティ構築への 道筋を探る}

本特別委員会は、このような動向を参看しつつ、 学術の立場から、「ヒューマン・セキュリティの構 築」の道筋を提唱すべく設置されている。その任務 は、伝統的な「安全保障」観から脱して、人々が人 間らしく「恐怖と欠乏から免れ平和のうちに生存す る」システムを構想することにある。したがって、 50 年にわたる学術会議活動において伝統的な平和 問題や安全保障の問題への取り組みの蓄積を発展的 に継承し再構成するだけでなく、経済の国際化・グ ローバル化、食糧・人口・環境などをめぐる地球規 模での課題、情報・通信・運輸などでのボーダーレス 化、科学技術の飛躍的発展などをも射程に入れて、 「現代の人類」に普遍的に妥当な「人間にふさわしい 安全と安心」のあり方について新たな提言を行う。

それは、第17期における「科学技術の発展と新た な平和問題」特別委員会および「安全に関する緊急 特別委員会」の活動を踏まえるとともに、第18期の 活動計画たる「現代の人類が共有している問題群の 解決策を学術の立場から提案」する「日本の計画」 の重要な部分を担うこととなるだろう。

この任務達成のためには、法学・政治学、経済 学・経営学、哲学・歴史学・社会学・教育学などの 人文・社会科学領域はもとより、医学、薬学、農学 をはじめ化学、生態学、さらには安全工学をはじめ とする工学や情報関係諸学の領域等による、学際的 で俯瞰的な統合的・融合的協働が必須となる。

本委員会は、以上の課題枠組みと任務設定に基づ
いて、最初に、国際政治において登場した「ヒュー マン・セキュリティ」の原意を確認し、あわせて 「セキュリティとセイフティ」の相互関係を確認し た上で、各委員が専門とされる領域から適切な素材 を選択していただき、当該領域で「現代の人類にと って何がヒューマンなセキュリティを脅かしている のか、その脅威を構造的に除去するシステムとプロ グラムは何か」を考察する問題提起をしていただい ている。

\section{委員会の活動状況}

これまでの委員会活動は、次のとおりである。 第1回委員会（2000年11月2日）

・役員選出および今後の委員会活動についての審 議

第2回委員会（2000年11月27日）

・役員の一部選出

・委員長から「活動の枠組み」につき提案、審議

·報告「ヒューマン・セキュリティの概念」岡部 委員 (2部)

第3回委員会（2000年12月21日）

- 委員長から今後の日程扣よび各報告領域・キー ワード等につき提案、審議

- 報告「安全学の可能性について」(久米委員・5 部)

第4回委員会（2001年1月22日）

・報告「医薬品と薬害」(古賀委員・7部)

- 報告「交通事故と非交通事故」(中村委員· 7 部) 第5回委員会（2001年2月16日）

・報告「21世紀アジア世界の安定と発展のために 
一日本近代史研究の視点から」(井口委員・1部)

- 報告「90年代の金融破綻処理」(村松委員・2部) 第6回委員会 (2001年3月22日)

・報告「電子媒体利用におけるセキュリティ」(吉 村委員・4部)

・報告「社会保障・社会福祉に見るヒューマン・セ キュリティの問題と国際貢献」(大橋委員・1部)

第7回委員会（2001年4月27日）

- 報告「環境会計について」(若杉委員・3部)

・報告「農業・農学におけるセキュリティ一一知 能的生産過程に打けるセキュリティ」（橋本委 員・6部)

今後さらに、経営学 (稲葉幹事・3部)、農業工学 (瀬尾幹事・6部)、生態学 (松本委員・4部)、宇宙 工学（松尾委員・5部）の諸領域から、多国籍企業 制御、食品・食糧、生態系保護、エネルギー問題な どについて、ヒューマン・セキュリティの観点から 報告をいただき検討を深めていく。

その後、7月の第10回委員会では中間的なまとめ を行うとともに、「日本の計画」委員会の審議とか かわらせつつ、本委員会の任務のしぼりこみをはか る予定である。もっとも、以上のような本委員会の 審議対象は、観点が異なるとはいえ、他の特別委員 会と相当以上に重複するところがあり、こうしたフ オーラムでの相互検討を経た上で、いずれかの段階 で相互調整と整備を要するであろう。

\section{「ヒューマン・セキュリティの構築」} 特別委員会

\begin{tabular}{|c|c|c|}
\hline 森 & 英樹 & （第2部） \\
\hline 稲葉 & 元吉 & (第3部) \\
\hline 瀬尾 & 康久 & （第6部） \\
\hline 井口 & 和起 & （第1部） \\
\hline 大橋 & 謙策 & （第1部） \\
\hline 岡部 & 達味 & （第2部） \\
\hline 村松 & 岐夫 & （第2部） \\
\hline 若杉 & 明 & (第3部) \\
\hline 松本 & 忠夫 & （第4部） \\
\hline 吉村 & 功 & （第4部） \\
\hline 久米 & 均 & （第5部） \\
\hline 松尾 & 弘毅 & （第5部） \\
\hline 橋本 & & (第6部) \\
\hline 古賀 & 憲司 & （第7部） \\
\hline 中村 & 紀夫 & （第7部） \\
\hline
\end{tabular}

森 英樹（もり ひでき 1942年生）

日本学術会議第2部会員、「ヒューマン・セキュリティの構築」 特別委員会委員長、「日本の計画」委員会幹事、公法学研究連絡 委員会幹事、中部地区会議代表幹事、名古屋大学大学院法学研究 科教授

専門：憲法学 